\title{
高エネルギ磁石のヒステリシス電動機への応用†
}

\author{
山田博 \\ 航空宇宙技術研究所 東京都調布市深大寺町 1880 \\ (昭和 45 年 11 月 13 日 受付)
}

\section{Application to a Hysteresis Motor of a High Energy Magnet}

\author{
Hiroshi YAMADA \\ (National Aerospace Laboratory, Chofu) \\ (Received November 13, 1970)
}

\begin{abstract}
A conventional hysteresis motor has a small ratio of the output power to the motor volume as compared with conventional induction motors, because the hysteresis material has a small hysteresis loop.

The author has proposed a new rotor structure in which anisotropic magnetic material Alnico 5 is utilized, which has a large hysteresis loop. The proposed hysteresis motor has a large ratio of the output power to the motor volume and a large starting torque as compared with conventional hysteresis motors.

This paper presents the principle, the structure, the voltage characteristics and the equivalent circuit of the proposed motor. The comparison of the theoretical and experimental values of the slip-torque characteristics is also given.
\end{abstract}

\section{1. まえがき}

近年ヒステリシス電動機はその長所としての，（i ） 騒音が非常に小さいこと，（ii） 起動時突入電流が小 さいこと, (iii) 負荷の急変に対して過渡振動が小さ いこと，(iv） 非同期時に蚛汓るトルク特に起動トル クが比較的大であることなどが買われ需用が伸びてい る.しかし出力の割には形状が大きくなることが欠点 であった. このことは, 従来の回転子構造でのヒステ リシス材料としては永久磁石として使用するものに比 乙保磁力が小さくなければならないことに起因してい る ${ }^{11}$. 最近同期電動機を 1 つの制御要素として使用す る分野も出現し ${ }^{2)}$ ， その同期特性のみならず起動特性， 小形化などの要求が高まりつつある，そのため著者は その構造を変えることによって保磁力, 残留磁束密度 ともに大きく，乙かも $(B H)_{\max }$ の大きな異方性材料 としてのアルニコ 5 系統のものを使うことを可能にし， 出力を増し同時に起動トルクも高め小形化とともに起 動特性を改善した $\dagger$ 第 8 回計測自動制御学会学術講演会で発表 (昭 44·8)
かにし，同期特よび起動特性を決める等価回路を導出 乙, その值を実測により求めた。 また試作電動機の起 動特性を決めるすべり特性抢よび同期特性を決める負 荷特性などを始めとする基本特性を示し従来のヒステ リシス電動機と比較するとともに計算值との比較を試 みた。

\section{2. 原理および構造}

\section{$2 \cdot 1$ ヒステリシストルク}

ヒステリシストルクが発生するためには使用するヒ ステリシス材料の $B-H$ 曲線がヒステリシスループを 描くことであり，そのループが包む面積がトルク発生

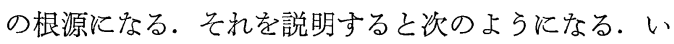
ま簡単のため回転磁界は理想的な正弦波であるとし， 回転子は静止の状態㐫るるのとする。また回転子の ヒステリシス材料は微小な磁区の集合として考兄られ， それぞれの磁区が向きを変えるためには非線形的な摩 擦力が働くものとする．ここで固定子によって生ずる 回転磁界が保磁力の十分高い永久磁石に上る機械的な 回転によって与兄られるものとすれば, この固定子磁 
石を定常状態で $d \theta$ だけ回転させた場合, 固定子磁石 がなす仕事 $d W$ は次式によって与兄られる.

$$
d W=T d \theta=\int_{v} \boldsymbol{H} d \boldsymbol{B} d v
$$

ここに, $T:$ ヒステリシストルク, $v:$ ヒステリシス 材料がしめる体積, $H$ : システリシス材料内の任意点 飞加わる磁界, $B$ ：ヒステリシス材料内の $H$ 飞対応し た任意点に和ける磁束密度.

ここで, 単位面積当たりの磁荷 $\boldsymbol{B}$ が外部磁界 $\boldsymbol{H}$ 中 飞存在している場合そこに力が発生し, 電動機として ながめた場合はトルクが生じている，そのトルクの大 きさは次の仮想仕事の原理から導かれる. それは, 固 定子磁石を $d \theta$ だけ回転させたため磁区が移動し, 磁 束密度としては $d \boldsymbol{B}$ だけ変化したことになる。そのと き, 磁区の移動にともなら単位体積当たりの仕事 $\boldsymbol{H}$. $d \boldsymbol{B}$ がヒステリシス材料内で熱エネルギに変化したこ とになる. 同時に, これは固定子磁石を $d \theta$ だけ回転 させたときになした仕事 $T d \theta$ から与兄られる。（1） 式を変形し次式を得る.

$$
\begin{aligned}
d W=T d \theta & =\int_{v}(\boldsymbol{H} d \boldsymbol{B}) d v=\int_{S}\left\{\int_{l}(\boldsymbol{H} d \boldsymbol{B}) d \boldsymbol{l}\right\} d \boldsymbol{S} \\
& =\int_{S}\left\{\left(\int_{l} \boldsymbol{H} d \boldsymbol{l}\right) d \boldsymbol{B}\right\} d \boldsymbol{S} \\
& =\int_{S}(U d \boldsymbol{B}) d \boldsymbol{S}=p \oint_{B}(U d \boldsymbol{S}) d \boldsymbol{B} \\
& =p\left(\oint_{B} U d \boldsymbol{B}\right) d \boldsymbol{S}
\end{aligned}
$$

ここに, $S$ : 磁束通路と直角な断面積, $l:$ 磁束通路に そった距離, $U=\int_{l} \boldsymbol{H} d \boldsymbol{l}, p:$ 対極数, $\oint_{B} U d \boldsymbol{B}:$ 七 ステリシス材料に与えられた回転磁界のもとでの単位 面積, 長さ $l$ 当たりのヒステリシスループの一巡にわ たる積分.

ただし，ヒステリシス材料は円周角いわゆる $\theta$ 飞関 して均一な材料からなっているものとし，また磁束の 通過方向は後に述べるょらに半径方向泿られるるの とする.したがって $\theta=2 \pi$ だけ固定子磁石を回転さ せた場合の仕事 $W$ として次式を得る。

$$
\begin{aligned}
W & =\int_{0}^{W} d W=\int_{0}^{2 \pi} T d \theta=2 \pi T=p \int_{S}\left(\oint_{B} U d \boldsymbol{B}\right) d \boldsymbol{S} \\
& =p \oint_{B} U d B \cdot S=p \oint_{\emptyset} U d \Phi
\end{aligned}
$$

ここに, $d \Phi=S d B$. Ф光にヒステリシストルクとして 次式を得る.

$$
T=\frac{p}{2 \pi} \oint_{\Phi} U d \Phi
$$

以上では磁界分布が正弦波として考光たが，これはル ープ積分にマイナループをも含めて考光れば(4)式は
固定子磁石による磁界分布が正弦波でない場合にも拡 張できる。また以上では一様な回転磁界とするため固 定子磁石の回転を使用したが，これは固定子電流がつ くる回転磁界が一様であるならば，それに対しても （4）式は成立する，この場合ヒステリシス材料で消費 されるエネルギは電源が供給することになる.さらに 以上では回転子が静止しているとして考兄たが，（4） 式からわかるようにヒステリシスループの包む面積が 回転子と回転磁界との相対速度に無関係に等しければ (4)式は相刘速度の関数とはならない.したがって静 止から同期直前までのヒステリシストルクはこの場合 一定となる。また(4)式からわかるようにヒステリシ ストルクは回転子のヒステリシス材料で消費される全 起磁力 $U$ と, その材料を通過する全磁束 $\Phi$ とでだい たい定まることになる．この $U, \Phi$ の值を大きくする には，どのような電動機の構造にするかが要点となり， これを次に検討する。

\section{2 構 造}

従来のヒステリシス電動機は Fig. 1 に示されるよ

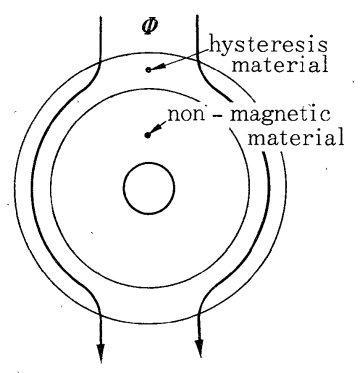

Fig.1 A sectional diagram showing the flux path of a conventional hysteresis rotor

ら飞磁束を回転子ヒステリシス材料の円周方向にそっ て通過させていた。これは内部が非磁性体であるため にそれよりも透䂭率が何十倍か高いヒステリシス材料 内を主として磁束は通過するためである. Fig. 1 でわ かるように，この構造は磁束の通過断面積が小さく通 過距離が長い特徴がある. 全起磁力の大きさは電動機 の温度上昇で制限されるため通過距離の長いことは七 ステリシス材料の透磁率をあまり小さくできないこと になる. そのため保磁力の比較的小さな材料を使用せ

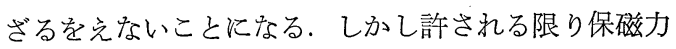
を高めるため全磁束の低いことを利用してみ望の断面 積を大きくとり銅損を少なく、できるだけ全起磁力 $U$ を高めるように設計してある. 限られた体積でより高 いトルクを発生させるためには, 保磁力に比較してヒ ステリシスループの包む面積のより大きな材料を使用 する必要がある。このような材料を生産性のよい現存 


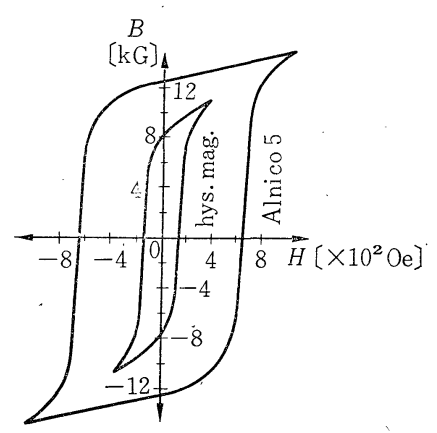

Fig. 2 Major hysteresis loops (hys. mag. : utilized a conventional hysteresis motor)

のものから求めると, 異方性で保磁力も割合に高く七 ステリシスループの角ばりの強いアルニコ 5 系統のも のが考觉られる. このアルニコ 5 と従来のヒステリシ ス材料の特性を比較すると Fig. 2 のようになる. こ のアルニュ 5 をとステリシス材料として使用すること を著者は考光, 電動機の温度上昇の観点から磁束通過 距離を短くする必要上 Fig. 3 亿示すように高透磁率

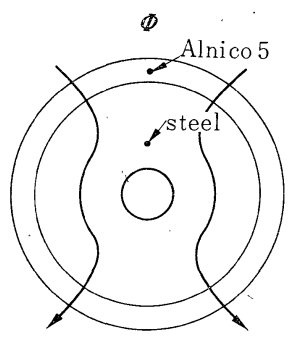

Fig. 3 A sectional diagram showing the flux path of hysteresis rotor proposed by the author

材料をとステリシスリング内にそう入することによっ て磁束を回転子の半径方向に通過させ，矢の磁石に特 ける通過距離を短縮させた。 この場合，全磁束 $\Phi$ は その通過断面積が大となるため大きくなり，それ合 った固定子を使用する必要がある，以上からわかるよ 亏に Fig. 1 の従来の低磁束で高励磁の銅機械的なる のに対し, Fig. 3 のアルニュ5を使ったものは高磁束 で低励磁の鉄機械的なものに高励磁性を加味したもの と見なすことがでさる。な掠，このとき使用するとス テリシス材料としてのアルニュ 5 の異方性方向は半径 方向であり，この異方性をつくるには Fig.4 のよう

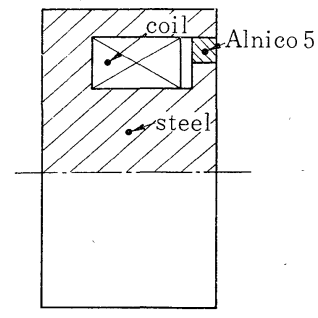

Fig. 4 A semi-sectional diagram of a equipment for making the radial anisotropic Alnico 5
な磁場冷却装置を使用する必要がある。すなわち赤熱 したリング状のヒステリシス材料を継鉄内にそう入し， 励磁コイルに直流電流を流し, 徐々に冷却するのであ る. この場合, 前もって磁場冷却装置を温めて扔かな いとヒステリシス材料の冷却が早くなり過ぎて所定の 特性が得られない，事実，この注意を払らことによっ て一般の磁場冷却装置で得られる特性に近い值が得ら れている、また，外周を真円にする加工法としてはせ ンタレス研削盤で行なうのが一般的な方法となうう。

Fig. 3 のような構造にした場合，空間高調波磁界が 増す傾向にあるが，これによるトルクの減少は主とし て表面部分に㨟いて生ずるためとステリシスループの 包む面積が大きな材料を使用することと，励磁強さを 調整することによって補ってあまりあるものである。 な招卜ルクの減少の原因の 1 つとしてのマイナループ の包む面積は, アルニコ 5 系統のものの方が従来の七 ステリシス材料のそれよりる小さくなる傾向にある. そのため，その点でも有利となる。

\section{$2 \cdot 3$ 誘導卜ルク}

ヒステリシス材料の固有抵抗が約 $50 \mu \Omega-\mathrm{cm}$ であ るため, そことは誘導電動機に拈汓るような誘導トル クが生ずる．また Fig. 3 亿示するのでは内部の高透 磁率材料としてむくの軟鋼を用いることができ，そこ 飞も誘導トルクが発生する。このため起動トルクが大 きくなる。

\section{$2 \cdot 4$ 同期トルクと起動トルクの関係}

従来のヒステリシス電動機に使われるとステリシス 材料の代表的なものはアルニュ系統のものであり，そ の成分の配合を調整して保磁力を $100 \sim 200 \mathrm{Oe}$ 程度 にした等方性のるのを使用している. そのため同期卜 ルクと起動トルクは密接な関倸がある。これはヒステ リシス材料そのものの性質からくる問題である。たと えば同期トルクいわゆる出力を高めようとすれば比較

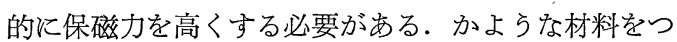
くろうとすれば成分の配合によって現技術では必然的 とその固有抵抗る高くなり起動トルクが低下する。 た起動トルクを高めようとすれば，いき特い低い保磁 力の材料を使うことになりヒステリシストルクが減少 するとともにヒステリシスループの形の変化のためマ イナループの包む面積が増すことと固有抵抗の減少に よって空間高調波によるトルクの減少も増し同期トル クが減少する。 しかし Fig. 3 に示したものでは同期 トルクの発生部分はヒステリシス材料としてのアルニ コ 5 の部分であり, 起動トルクの発生部分は内側の高 透磁率材料の部分である. そのため同期トルクと起動 トルクを招の扮の独立に高めることが可能となり，形 
の大きさに比し起動時間が小さく出力の大きい同期電 動機を設計することが可能となる。

\section{5 試作電動機の仕様}

試作した電動機に実際に使用した材料㔚よび仕様を 次淙守.

（1）回転子ヒステリシス材料：NFW-7, 外径 $54.4 \mathrm{~mm} \phi$, 内径 $45 \mathrm{~mm} \phi$, 厚さ $5 \mathrm{~mm}$ のものを 6 個重和 $5 \mathrm{~mm} \times 6=30 \mathrm{~mm}$ の軸方向の長さとして使用, （2）回転子鉄心：炭素鋼 $\mathrm{S} 10 \mathrm{C}$, 外径 $45 \mathrm{~mm} \phi$, 内 径 $10 \mathrm{~mm} \phi$, 長さ $30 \mathrm{~mm}$, (3) 軸 : 炭素鋼 $\mathrm{S} 45 \mathrm{C}$, 外径 $10 \mathrm{~mm} \phi$ のもの，（4）固定子成層鉄心：珪素 鋼板 $\mathrm{H}_{18}$, 外径 $100 \mathrm{~mm} \phi$, 内径 $55 \mathrm{~mm} \phi$, 厚さ 0.5 $\mathrm{mm}$ のものを 60 枚成層し長さ $30 \mathrm{~mm}$ として使用, 溝数 24 , 半開口溝, (5) 固定子巻線: $50 \mathrm{~Hz}, 190$ $\mathrm{V}, 0.8 \mathrm{~A}, \mathrm{E}$ 種絶縁, 3 相, 2 極, 星形結線, 8 ピ ッチ重水巻, 毎相毎極 $0.45 \mathrm{~mm} \phi$ で 65 巻数の 4 コイ ル，(6）空げき：0.3 mm，（7） 最高出力： $70 \mathrm{~W}$, （8） 力率： $46 \%$ ，（9） 最高出力時の効率 : $58 \%$, （10）回転子慣性能率：1.9 kg- $\mathrm{cm}^{2}$ ，（11） 初期加速 度 $(T / J): 2.4 \times 10^{3}\left[\mathrm{rad} / \mathrm{s}^{2}\right]$.

\section{3. 電圧特性および等価回路}

一般にヒステリシス電動機はヒステリシスループの 包む面積を利用している. そのヒステリシスループそ のものが非線形性に基づくものなのでその解析は複雑 となり害用性を欠くうれいがある。また固定子溝に基 づく空間高調波の影響も大きく表われるため，それら をる含めた解析となると更腹襍となり実用性も失な わ扎る。

事実メーカでは基本設計に関する若干の論文が発表 されている4) ともかかわらず定性的な概念と実験に基 づいて設計を行ないカットアンドトライ方式を採用し ているのが実状である．これは著者が試作した種の七 ステリシス電動機にもいえることで，この非直線性が ぞの程度のものであるかを実測とよって以下明らかに して路く.

\section{$3 \cdot 1$ 電圧特性}

試作電動機の電圧特性としてのトルク呿よび電流対 電圧特性を Fig. 5 亿示す。この特性にも現われるよ らに主としてヒステリシストルクを含む同期トルクの 非直線性が目立っている。これはとうぜん予期される ことでヒステリシスループの包む面積の飽和とみぞに よる空間高調波によるものであるが，果たしてヒステ リシスループの包む面積の何割程度のヒステリシスト ルクが失なわれているかを調べて見るため次式の $\eta$ を 定義する.

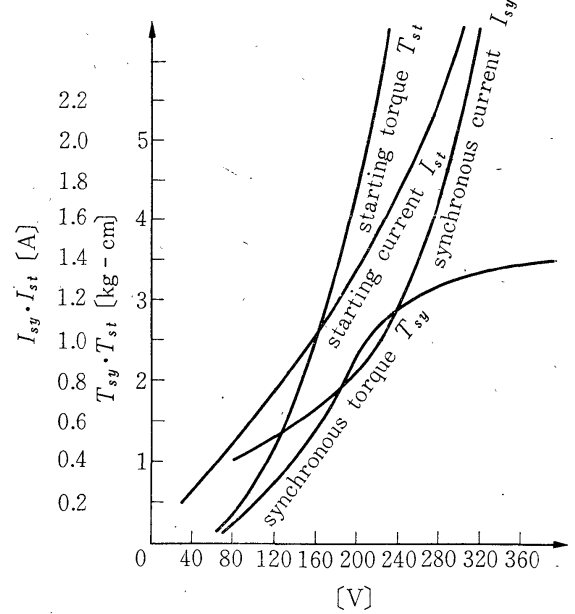

Fig. 5 Voltage characteristic of the trial production hysteresis motor

$\eta=\frac{(\text { 使用状態に拈ける最大同期トルク） }}{\text { (ヒステリシスループの包む最大面積から計算したトルク） }}$

これを求めると次式のようになる。

$$
\eta \doteqdot \frac{3.5 \mathrm{~kg}-\mathrm{cm}}{7 \mathrm{~kg}-\mathrm{cm}}=0.5
$$

これは従来の形のものと大差はない，したがって，ヒ ステリシス材料を実際の電動機汇組み込んで動作させ た場合には，理想的な回転磁界として計算で求めた卜 ルクの約半分が失なわれることになる。これからもわ かるように定量的な解析を実際と一致させるためには， いか腹襍となるかが想像される。しかし，ある一定 の周波数とある一定の電圧に特沙る起動から同期にわ たる解析は，近似的湶形化して等価回路として表わ した場合，定性的な概念のはあくに大い役立ち，ま た実測によってその定数を定めれば定量的にるトルク， 効率, 力率, 電流, インピーダンスなどの大体の值の はあくに役だつるのと思われる。

また Fig. 5 の電圧特性に和いて, 起動電流と同期電 流の比が誘導電動機に比し小さい割に起動トルクが大 きいのは，回転子抵抗が比較的大きく最大トルクのす べりの位置が起動時のそ机に近づいていることと起動 時に执いてもヒステリシストルクが存在しているため である。また従来のヒステリシス電動機と比較すると 起動電流の值が同期電流の値に比し大きくなっている のは回転子抵抗が従来のものに比し小さいためで, こ 机は回転子内部の鉄心にむくの軟鋼が存在しているた めであり，これは同時に起動トルクも大きくしている。

\section{$3 \cdot 2$ 等価回路の導出}

一般に誘導電動機の 1 相に対する等価回路は Fig. 6 


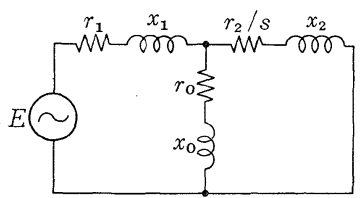

Fig. 6 Equivalent circuit of a conventional induction motor

のようである。ここに $r_{0}+j x_{0}$ は励磁アドミッタンス の逆数である. ヒステリシス電動機に扔いてはこの $x_{0}$ の部分がヒステリシストルクの発生源となる．ここで 試作電動機の等価回路を導出するにあたり, 交献5)の 等価回路に比し，トルク対すべり特性を求めるための 計算の簡潔性を考慮して次のように求める。 また，従 来示されなかった固定子みぞの高調波磁界に基づく損 失がすべり s、によって異なることを考慮した等価抵抗 とか，同期状態汇扔いての負荷変化によるインピーダ ンス変化を表わす等価回路る同時に求める.

いま試作電動機の，ある 1 相の巻線に流れる励磁電 流 $I_{0}$ （励磁インピーダンスを通る電流）を次式で示す.

$$
I_{0}=I_{m} e^{j \omega t}
$$

この電流と他の 2 相の励磁電流によって回転子のヒス テリシス材料内に理想的な回転磁界 $H$ が生じている ものとし，それを次式で示す。

$$
H=H_{m} e^{j(\omega t-p \theta)} .
$$

ここそ, $\omega$ : 電源角周波数, $\theta$ : 考光ている固定子巻線 のある磁極の中心を基準にした円周角, $p$ : 対極数. ここで回転子材料の透磁率 $\mu$ を磁界 $H$ 亿乗じた值が 磁束密度である。この場合, 回転子材料がヒステリシ ス損失をもたない材料であればその透磁率性実数で あるが，ヒステリシス電動機ではそのヒステリシス損 失を利用する関係上; 回転子材料がヒステリシス材料 であるがため透磁率 $\mu$ は複素数となる。すなおちとス テリシス材料の複素透磁率 $\mu$ を $\mu_{r}-j \mu_{i}$ の形に表わ して解析する.

な特，ここではヒステリシス材料の，ある一定の励 磁電流のもとでのヒステリシスループをそれと等価な だ円と見なしている。したがって，回転子が同期速度 に達する以前で㴽磁束密度 $B$ として次式を得る.

$$
\begin{aligned}
B=\mu H=\left(\mu_{r}-j \mu_{i}\right) H_{m} e^{j(\omega t-p \theta)} & =|\mu| H_{m} e^{-j \phi} e^{j(\omega t-p \theta)} \\
& =|\mu| H_{m} e^{j(\omega t-\phi-p \theta)}
\end{aligned}
$$

$$
\text { ここに, } \quad|\mu|=\sqrt{\mu_{r}{ }^{2}+\mu_{i}{ }^{2}}, \quad \phi=\tan ^{-1} \frac{\mu_{i}}{\mu_{r}}
$$

要するに磁界が加兄られて磁束密度が生ずるまでには 磁区の回転にとるなら非線形摩擦力のためいくぶんか の時間的遅れが生ずる，その程度を示すのが(9)式の фである. 次に，考兄ている巻線に鎖交する全鎖交磁
束 $\Psi$ として次式を得る.

$$
\begin{aligned}
& \Psi \propto 2 n p \int_{-\pi / 2 p}^{\pi / 2 p} B d \theta \\
: & 2 n p\left(\mu_{r}-j \mu_{i}\right) H_{m} \int_{-\pi / 2 p}^{\pi / 2 p} e^{j(\omega t-p \theta)} d \theta \\
= & 2 n p\left(\mu_{r}-j \mu_{i}\right) H_{m}\left|\frac{e^{j(\omega t-p \theta)}}{-j p}\right|_{-\pi / 2 p}^{\pi / 2 p} \\
= & 2 n p\left(\mu_{r}-j \mu_{i}\right) H_{m} \frac{2}{p} e^{j \omega t} \\
= & 4 n\left(\mu_{r}-j \mu_{i}\right) H_{m} e^{j \omega t}
\end{aligned}
$$

ここに, $n: 1$ 相 1 極当たりの巻数.

したがって 1 相巻線汇誘起する電圧 $E$ は次式とな る.

$$
\begin{aligned}
& E \propto-\frac{d \Psi}{d t} \propto-\frac{d}{d t}\left(\mu_{r}-j \mu_{i}\right) H_{m} e^{j \omega t} \\
= & -j \omega\left(\mu_{r}-j \mu_{i}\right) H_{m} e^{j \omega t}
\end{aligned}
$$

ゆ兄に両端子間の端子電圧は符号を逆に乙 $H_{m} e^{j \omega t} \propto$ $I_{0}=I_{m} e^{j \omega t}$ を考慮して次式を得る。

$$
\begin{aligned}
V & \propto j \omega\left(\mu_{r}-j \mu_{i}\right) H_{m} e^{j \omega t}=\left(\omega \mu_{i}+j \omega \mu_{r}\right) H_{m} e^{j \omega t} \\
& \propto\left(\omega \mu_{i}+j \omega \mu_{r}\right) I_{0}
\end{aligned}
$$

端子電圧 $V$ と電流 $I_{0}$ の比がその端子間のインピーダ ンスであり，そのインピーダンス $Z_{0}$ は次式で与兄ら れる。

$$
Z_{0}=\frac{V}{I_{0}}=R_{0}+j X_{0} \propto \omega \mu_{i}+j \omega \mu_{r}
$$

(13)式からわかるように回転子にヒステリシスループ を有しない材料を使った場合は (13) 式の $\omega \mu_{i}$ の項は 生じない， $\mu_{i}$ の存在いわゆる磁束が磁界に対して遅

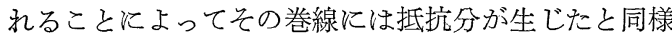
な作用を呈するのである。商用周波数帯まではとステ リシスループの包む面積が $\omega$ に無関係で汪とんど一定 であることを考觉ると $\mu_{i} \propto 1 / \omega$ となり抵抗分は $\omega$ と 無関係に一定な値となる.この $R_{0}$ を誘導電導機に特 けると同様江出力を示す成分之熱エネルギに变わる成 分とに分けると次のよらになる。

出力に対応する抵抗 $R_{01}=(1-s) R_{0} \propto(1-s) \omega \mu_{i}$

回転子損失飞対応する抵抗 $R_{02}=s R_{0} \propto s \omega \mu_{i}$

ただし,$\quad R_{01}+R_{02}=R_{0} \propto \omega \mu_{i}$

な和回転子のみぞによる空間高調波の影響は渦電流損 によるものとヒステリシス損によるものとがあり，そ れぞれすべり $s$ 関する複雑な関数となららが，ここ では簡単化のためそれらの合成損失に対応する損失抵 抗として励磁回路之回転子回路にそれぞれ直列にはい る抵抗 $r_{0}, r_{2}$ で近似的に対応させることにする．さ らに同期状態飞执いては近似的には回転子飞永久磁石 を使用した永久磁石電動機のような動作となり，負荷 の增減によって回転子に加わる磁界之残留磁束密度の 
ずれの円周角いわゆる内部相差角の増減となって現わ れる，それを近似的に線形と又なし次式によって定義 する.

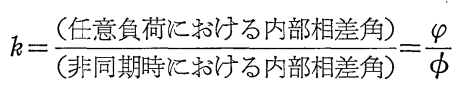

この場合, 永久磁石回転子と異なることは回転子の磁 束密度が内部相差角によってある程度変化する点であ る.また永久磁石電動機と考光ればとらぜん励磁回路 に起電力をそう入した解析法が考学られるが，ここで は簡単化のためそれと等価なインピーダンスとして考 えることにする. 以上のことと $s>0$ のときは $k=1$ な ることを考慮して試作電動機の 1 相あたりの等価回路 として Fig. 7 を得る. ここに $X_{k}$ は内部相差角の変

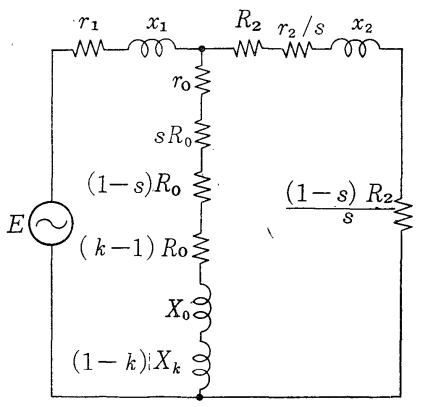

Fig. 7 Equivalent circuit of the hysteresis motor proposed by the author

化によって励磁リアクタンスが変わるため，その変化 を示すために導入したリアクタンスである.

\section{$3 \cdot 3$ 等価回路の定数の実測}

（1） 1 次抵抗 $r_{1}$ 回転子を除去し定格電流 $I$ を流した状態での 1 相あたりの入力電力を $P$ とすれ ば次式から求まる。

$$
r_{1}=\frac{P}{I^{2}}
$$

（2） 1 次漏えいリアクタンス $x_{1}$ 回転子を除 去し定格電流 $I$ を流した状態での 1 相あたりの無効電 力を $Q$ とす机ば近似的次式から求まる.

$$
x_{1}=\frac{Q}{I^{2}}
$$

この場合，回転子のかわりに銅で充満しても大差ない 結果が得られた。

(3) 励磁損失抵抗 $r_{0}$ 定格電圧の同期運転状 態 $(s=0)$ では 2 次回路は開放状態々なり,さらに無 負荷 $(k=0)$ にすることによって $R_{0}$ の項が消光，そ のときの 1 相あたりの入力電力より 1 次銅損を差引く ことによって励磁損失を求めそれを $P$ とすれば，そ のときの線電流を $I$ として次式から求まる.

$$
r_{0}=\frac{P}{I^{2}}
$$

（4）ヒステリシス抵抗 $R_{0}$ 定格電圧での 同期 運転 $(s=0)$ の同期脱出寸前の負荷状態 $(k=1)$ に拉 ける入力電力を $P$ とし，そのとさの線電流を $I$ とし て次式で求まる.

$$
R_{0}=\frac{P}{I^{2}}-r-r_{0}
$$

（5）励磁リアクタンス $X_{0}$ 定格電圧での同期 脱出寸前 $(k=1)$ の同期運転状態 $(s=0)$ に和㺭る 1 相あたりの無効電力之線電流を $Q, I$ とすれば次式で 求まる.

$$
X_{0}=\frac{Q}{I^{2}}-x_{1}
$$

（6）内部相差角に関係するリアクタンス $X_{k}$ 定格電圧での無負荷 $(k=0)$ 同期運転 $(s=0)$ 状態 で，1相あたりの無効電力と線電流を $Q, I$ とすれば 次式で求まる.

$$
X_{k}=\frac{Q}{I^{2}}-x_{1}-X_{0}
$$

（7） 2 次インピーダンス $Z_{2}=R_{2}+r_{2}+j x_{2}$ 定 格電圧で回転子を拘束した状態 $(s=1, k=1)$ での 1 相めたりの電力, 無効電力, 線電流和よびインピーダ ンスを $P, Q, I$ 特よび $Z$ とすればインピーダンス $Z$ として次式を得る。

$$
Z=\frac{P+j Q}{I^{2}}
$$

また, $Z=Z_{1}+\frac{1}{Y_{0}+Y_{2}}$

ゆえに $Z_{2}$ として次式を得る。

$$
Z_{2}=\frac{Z-Z_{1}}{1-Y_{0}\left(Z-Z_{1}\right)}
$$

ここに,

$$
Z_{1}=r_{1}+j x_{1}, \quad Y_{0}=\frac{1}{r_{0}+R_{0}+j X_{0}} ; \quad Z_{2}=R_{2}+r_{2}+j x_{2}
$$

この場合，回転子を拘束して定格電圧を印加してもそ れほどの電流増加はなく短時間では焼損の心配はない。

（8） 2 次損失抵抗 $r_{2}$ 定格電圧で回転子を拘束 した状態 $(s=1, k=1)$ での 1 相あたりの入力電力, 同期ワット，線電流，励磁電流特よび 2 次電流を $P_{\hat{\imath}}$, $P_{0}, I_{1}, I_{0}$ 预よび $I_{2}$ とすれば次式で求まる.

$$
r_{2}=\frac{P_{i}-P_{0}-r_{1} I_{1}{ }^{2}-r_{0} I_{0}{ }^{2}}{I_{2}^{2}}
$$

ここに同期ワットとはこの場合のトルクいわゆる起動 トルク $T$ に同期角速度 $\omega_{0}$ を乗じたものである.

以上の方法で試作電動機について各定数を求めると Fig.8のようになる. Fig. 8 でわかるように，この種 の電動機は従来のヒステリシス電動機に比し高インピ. 


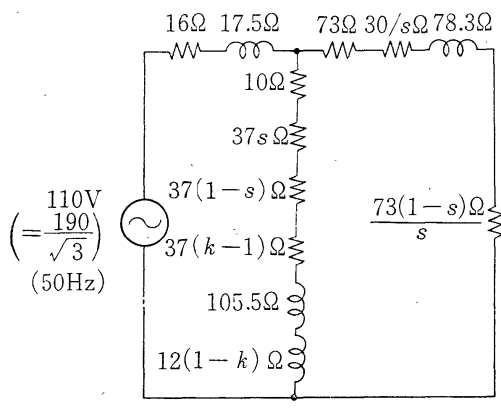

Fig. 8 Constants in the equivalent circuit of the trial production hysteresis motor

一ダンスであることがわかる。これはヒステリシス材 料のヒステリシスループの包む面積が大きいことによ って生ずる等価抵抗 $R_{0}$ の増大と, 全磁束 $\Phi$ が大きい ことによる等価リアクタンス $X_{0}$ の増大によるためで ある. このため, この試作電動機は效率の点でまさる が力率の点では劣ることになる.

\section{4. 起動および同期特性}

\section{$4 \cdot 1$ 起 動 特 性}

電圧を印加して同期速度に達するまでの時間をてと 乙, 過渡電流の影響を無視して次式を得る。

$$
\begin{gathered}
\tau=\int_{0}^{\tau} d t=\int_{0}^{\omega_{0}} \frac{d \omega_{m}}{\alpha}=\left(J+J_{L}\right) \int_{0}^{\omega_{0}} \frac{1}{T-T_{L}} d \omega_{m} \\
=-\omega_{0}\left(J+J_{L}\right) \int_{1}^{0} \frac{1}{T-T_{L}} d s \\
\because \quad \alpha=\frac{d \omega_{m}}{d t}, \quad\left(J+J_{L}\right) \alpha=T-T_{L}
\end{gathered}
$$

ここに, $\omega_{m}$ ：任意時間 $t$ に和将る回転子の角速度, $\omega_{0}$ : 回転子の同期角速度, $\alpha$ : 回転子の角加速度, $J$ : 回転子の慣性能率, $J_{L}$ : 回転子軸に換算した負荷の慣 性能率, $T$ : 電動機の発生トルク, $T_{L}$ : 負荷トルク, $s:$ すべり $\left(\frac{\omega_{0}-\omega_{m}}{\omega_{0}}\right)$.

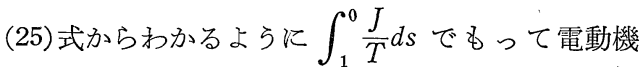
の起動特性の目やすとなる. したがって $T$ 対 $s$ の特 性いわゆるすべり特性和よび慣性能率Jの比較で，そ れぞれの電動機の起動特性を比較することができる.

Fig. 9 に同一固定子和よび同じ外径寸法をもつ回転子 を使用した場合の従来のヒステリシス電動機と試作電 動機の比較がなされている.この場合，ともに $\mathrm{E}$ 種 絶縁のため電動機損失電力がだいたい等しいとみるこ とができ, 試作電動機の入力電力は従来のものに比し 約 1.6 倍となる. Fig. 9 で試作電動機のトルクは従来 のものの約 3 倍となっている．しかし慣性能率は内部 鉄心が高透磁率材料であるためアルミ合金より重くな

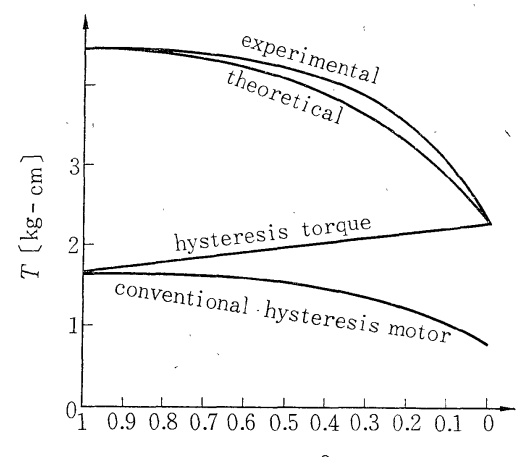

Fig. 9 Slip-torque characteristic of the conventional and the trial production hysteresis motors (rating conditions)

るので従来のものの約 1.5 倍となる. したがって，起 動時間てとしては拉よそ従来のものに比し半分となり 起動特性は 2 倍とよくなっている. また, Fig. 8 の等 価回路から計算で求めたトルク $T$ 対すべり $s$ の特性 が Fig.9 に示され実測值との比較がなされている. 同時にヒステリシストルクと誘導トルクを分けて示し てもある.な括，この計算值は Fig. 7, Fig. 8 を参照 し $k=1$ を考虑した次式による.

$$
\omega T=\omega T_{0}+\omega T_{2}=3\left\{\left|I_{0}\right|^{2}(1-s) R_{0}+\left|I_{2}\right|^{2} \frac{(1-s)}{s} R_{2}\right\}
$$

ゆえに,

$$
T=3 \frac{\left|I_{0}\right|^{2}(1-s) R_{0}+\left|I_{2}\right|^{2} \frac{1-s}{s} R_{2}}{(1-s) \omega_{0}}=3 \frac{\left|I_{0}\right|^{2} R_{0}+\left|I_{2}\right|^{2} \frac{R_{2}}{s}}{\omega_{0}}
$$

ここに, $T_{0}$ : ヒステリシストルク $T_{2}$ : 誘導トルク,

$$
\begin{aligned}
& I_{0}=\frac{\frac{R_{2}+r_{2}}{s}+j x_{2}}{\frac{R_{2}+r_{2}}{s}+r_{0}+R_{0}+j\left(x_{2}+X_{0}\right)} I_{1}=f(s) \\
& I_{2}=\frac{r_{0}+R_{0}+j X_{0}}{\frac{R_{2}+r_{2}}{s}+r_{0}+R_{0}+j\left(x_{2}+X_{0}\right)} I_{1}=g(s)
\end{aligned}
$$

ただし

$$
I_{1}=\frac{E}{r_{1}+j x_{1}+\frac{\left(\frac{R_{2}+r_{2}}{s}+j x_{2}\right)\left(r_{0}+R_{0}+j X_{0}\right)}{\frac{R_{2}+r_{2}}{s}+r_{0}+R_{0}+j\left(x_{2}+X_{0}\right)}},
$$

$E:$ 相電圧

以上の式に実測で求めた実数（Fig. 8 の值）を代入 しすずり $s$ に対するトルク $T$ の関係を計算したの が Fig. 9 に示した計算值である.この計算值は $s \fallingdotseq$ 0.3 近辺を除いてょく一致している. 実測值はいくぶ 
んか深文ぞ形の特性が加味された $(s \fallingdotseq 0.3$ 近辺で凸部 をるっている） 2 次抵抗の大きい誘動電動機の特性が ヒステリシンストルクの特性に加わったものとなってい る、乙かし深みぞ形の等価回路とすると複雑さを増し 実用的でない和それが生ずる. しかし Fig. 7 の等価回 路で実用上は十分利用できるるのである。したがって この等価回路で実用的な定量性を加味した傾向を求め ることができる．ただしこ机は周波数と供給電圧を一 定とした状態でのものであることを忘れてはならない

\section{2 同期特性}

同期運転状態に和いて負荷が急変した場合，新しい 内部相差角 $\varphi_{0}$ になるまでに一般に過渡振動が発生す る. その様子は次式によって表わされる.

$$
\left(J+J_{L}\right) \frac{d^{2} \varphi}{d t^{2}}+R \frac{d \varphi}{d t}+K \varphi=T_{L}
$$

ここそ, $J$ : 電動機の回転子の慣性能率, $J_{L}$ : 電動機 軸に換算した負荷の慣性能率, $R=\frac{1}{\omega_{0}}\left(\frac{\partial T}{\partial s}\right)_{s=+0}+R_{L}$, $R_{L}:$ 負荷の制動係数,

$$
K=\left(\frac{\partial T}{\partial \varphi}\right)_{\varphi=\varphi_{0}} \text { (これを同期化力という). }
$$

Fig. 10 そ，同じ固定子を使用した場合の従来のも

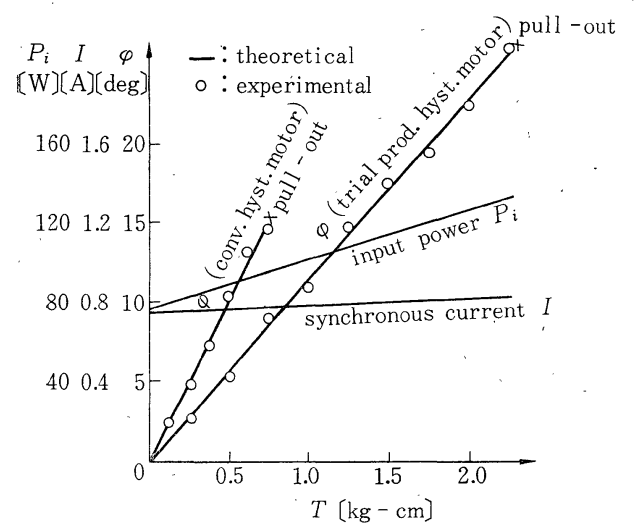

Fig.10 Loading characteristics of the conventional and the trial production hysteresis motors (rating conditions)

のと試作電動機の負荷に対する内部相差角の関係の実 測値が示してある.いま, $J_{L}=R_{L}=0$ とした場合の固 有角振動数 $\omega_{n}$ とダンピング係数 $\zeta=\delta / \omega_{n}(\delta:$ 減衰 定数 $=R / 2 J)$ は次式のようになる.

$$
\left.\begin{array}{rl}
\omega_{n}^{\prime} & =\sqrt{\frac{K}{J}}=\sqrt{\left(\frac{\partial T}{\partial \varphi}\right)_{\varphi=\varphi_{0}}} / J \\
\zeta & =\frac{\delta}{\omega_{n}}=\sqrt{\frac{J}{K}} \cdot \frac{R}{2 J}=\frac{R}{2 \sqrt{K J}} \\
& =\frac{1}{\omega_{0}}\left(\frac{\partial T}{\partial s}\right)_{s=+0} / 2 \sqrt{\left(\frac{\partial T}{\partial \varphi}\right)_{\varphi=\varphi_{0}} \cdot J}
\end{array}\right\}
$$

Fig. 9，10 の実測值よりこれらを比較すると，従来の ヒステリシス電動機に比し試作電動機は $k$ がだいたい 2 倍に，J がだいたい 1.5 倍に，そして $R$ がだいた い3 倍になる. したがって $\omega_{n}$ が 1.15 倍に，そして

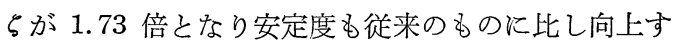
る. これはとくに $R$ の增加による影響が働いている ためである．また，同期脱出時あるいは非同期時にお。 ける内部相差角 $\phi=\varphi_{m}$ を実測で求めると $25^{\circ}$ となる. それ以下の任意の $\varphi$ に和ける負荷トルクを Fig. 8 か ら計算で求めると Fig. 10 のように汪とえど直線とな る.な特この計算式は次式による。

$$
T=3 \frac{\left|I_{0}\right|^{2} k R_{0}}{\omega_{0}}=\frac{3\left|I_{0}\right|^{2} R_{0} \frac{\varphi}{\phi}}{\omega_{0}}=f(\varphi)
$$

ここに,

$$
I_{0}=\frac{E}{r_{1}+r_{0}+k R_{0}+j\left(x_{1}+X_{0}+X_{k}-k X_{k}\right)}, \quad k=\frac{\varphi}{\phi}
$$

内部相差角と負荷トルクの関係は同期脱出までは注と んぞ計算値，実測値とも直線的である。したがって (15)式の仮定は実際にかなり近いとみてよい。また線 電流呿よび入力電力対負荷トルクとの関係も Fig. 10 に示してあり, 線電流の変化はかなり小さい。これは 励磁リアクタンスが大きいためである.

\section{5. むすび}

ヒステリシス材料としてアルニコ 5 を使うことによ って，電動機の大きさに比較して大きな出力が得られ た，同時に，起動トルクも大きく，安定度もよく，ま た起動括よび同期特性のよい同期電動機が得られた. しかし，この種電動機では固定子として珪素鋼板から なる成層鉄心を用いることとヒステリシス材料に特い

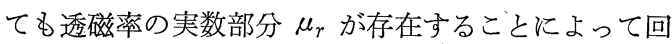
路にインダクタンスを有し，それを抵抗とで定まる時 定数に関係する過渡現象が発生する，その場合の過渡 電流としての直流電流によって生ずる制動トルクのた め，それが影響する程度になると，むはやそれ以上の 起動時間の短縮は望めなくなる。これはヒステリシス 電動機である限り常に付随する問題である. しかし普 通の $\mathrm{AC}$ サーボモータに匹適する程度の初期加速度の 值が得られる可能性は十分にある. またヒステリシス 電動機では定速度を得るためのフィードバック系はそ の電動機自体の機能に包含されていると考省ることが でき，段階的な定速度とある程度の起動時間の短縮を 目指すものではフィードバック系を必要とせず, 経済 的に有力な制御要素とみることができる!な特，起動 時間の問題は起動時間のみならず，ある向きの同期速 
度より他の向きの同期速度に移る時間とか，同期速度 から停止にいたる時間の問題にも容易に発展させるこ とがでさる。

本報告の目的は，ここで述べたような形の起動特性 および同期特性に富んだヒステリシス形同期電動機を 提案すると同時に，その特性を示し，さらにその設計 に必要なある程度の定量性を加味した概念を得るため の等価回路を誘導し，実用化への発端となさしめるこ とでありこの点は提供できたと思っている.

終わりに，本研究にさいし種々とご援助をたまわっ た日本特殊鋼(株)技術係長の吉野泰文氏，(株)大東製 作所専務取締役の田村正四郎氏ならびにコロナモータ
(株)常務取締役工場長の板谷秀夫氏をはじめとする多 くのかたがたに深く感謝する。

$$
\text { 参 考 文 献 }
$$

1) Parker, Studders : Permanent Magnets and Their Application, John Wiley and Sons, Inc. (1962)

2) Kraver : Position Control with a Synchronous Motor, Control Engineering, 17-5, 66/71 (1970)

3）山田：アルニコ 5 を使ったヒステリシス電動機，第 8 回計測自動制御学会学術講演会論文集, $643,497 / 498$ (1969)

4）中村・大川・加藤 : ヒステリシス電動機の基本設計, 電気学会誌, 88-6-957, 112/120 (1968)

5）宮入・片岡 : ヒステリシス電動機の基本等価回路，電 気学会誌, 85-10-925, 118/126 (1965)

\section{論 文集論文に対する討論の募集}

$\diamond$ 会員相互の知識の交換のため，論文集には寄書欄を設けてあります。

$\diamond$ 新しい着想や学術上の所見はもとより，実験結果または論文集の論文に対する質問・討 論・意見などなるべく短くまとめて（0.5〜2 ページ以内）御投稿ください。

昭和 47 年 5 月 25 日までの投稿は次号に掲載されるよう努力します. 